\title{
Outbreak of jellyfish envenomations caused by the species Olindias sambaquiensis (CNIDARIA: HYDROZOA) in the Rio Grande do Sul state (Brazil)
}

\author{
Vidal Haddad Junior ${ }^{[1]}$, Maurício Azevedo de Oliveira Costa ${ }^{[2]}$ and Renato Nagata ${ }^{[3]}$
}

[1]. Universidade Estadual Paulista Júlio de Mesquita Filho, Faculdade de Medicina de Botucatu, Departamento de Dermatologia e Radioterapia, Botucatu, SP, Brasil.

[2]. Universidade Federal do Rio de Janeiro, Instituto de Doenças do Tórax, Rio de Janeiro, RJ, Brasil.

[3]. Universidade Federal do Rio Grande, Laboratório de Zooplâncton, Rio Grande, RS, Brasil.

\section{Dear Editor:}

The Southern region of Brazil has been experiencing epidemic peaks of jellyfish related injuries in recent years ${ }^{1-7}$. Although the causative species are autochthonous, environmental and anthropogenic factors certainly provoke the increase of envenomations in the region ${ }^{7}$. Currently, during the summer, hundreds of thousands of injuries are registered, mainly in the Paraná and Santa Catarina states ${ }^{1,2,5}$. These occurrences are foreseeable and preventive measures and initial treatments such as signaling beaches with enormous presence of jellyfish and distributing material with first-aid information, including using compresses of cold sea water and vinegar baths, as well as occasional oral analgesia, are already carried out in the affected areas ${ }^{2,5,8,9}$.

The most common species associated with accidents in the southern region are the scyphomedusa Chrysaora lactea and the hydromedusa Olindias sambaquiensis ${ }^{1,2,5}$. (Figure 1). These are small cnidarians, with relatively short tentacles $(\sim 20 \mathrm{~cm})$, whose venom, contained in the nematocysts, causes intense pain but rarely causes systemic manifestations (cardiac or respiratory failure, observed in Portuguese man-o'war and cubomedusae injuries $)^{2,5}$. In some swimmers, serial envenomations can cause allergic phenomena of varying severity ${ }^{8,9}$. An important factor for the evaluation of the severity of the envenomation is the observation of erythematous plaques on the victims' skin as the most serious injuries are caused by cubomedusae and Portuguese

Corresponding author: Dr. Vidal Haddad Junior. e-mail: vidal.haddad-junior@unesp.br

Orcid: 0000-0001-7214-0422

Received 4 April 2019

Accepted 26 July 2019

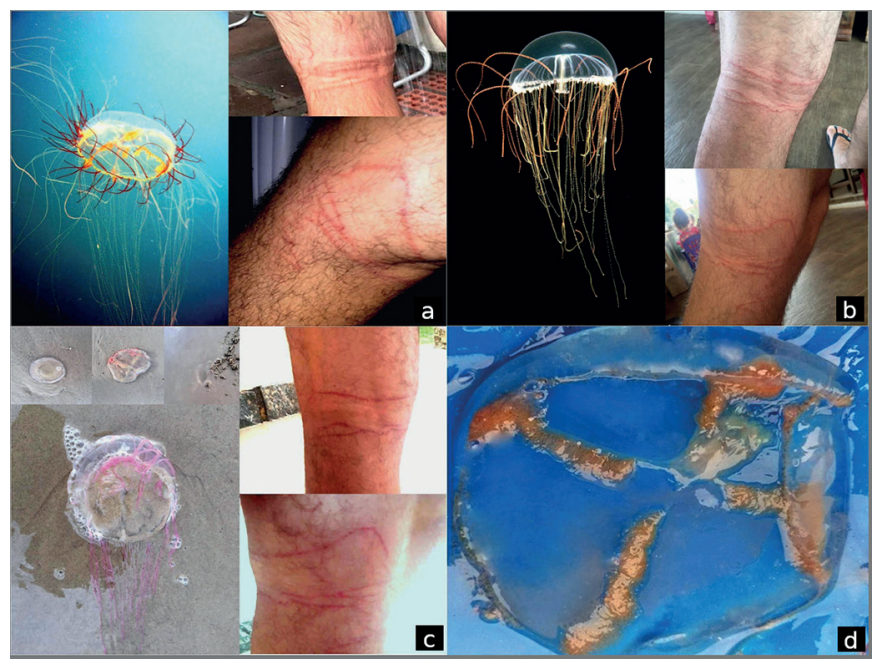

FIGURE 1: Olindias sambaquiensis (live specimens in the water, on the beach and specimen in the laboratory $(a, b, c, d)$. Sequence of an envenomation caused by $O$. sambaquiensis at Tramandaí beach at the time of occurrence, after 24 and $48 \mathrm{~h}$ (a, b, c).

Photos: Fábio Lang da Silveira, Álvaro Esteves Migotto e Mauricio Azevedo de Oliveira Costa.

man-o'war, which cause a small number of long, criss-crossed marks (corresponding to the tentacles) that are more than 20 $\mathrm{cm}$ in length. However, injuries caused by $C$. lactea and $O$. sambaquiensis leave rounded, short marks that correspond to the body and the tentacles of the animal ${ }^{8,9}$. The observation of these signs suggests a good prognosis for the victim. In the various outbreaks observed in the region, an alternation of these two species, always with absolute the predominance of one species was noted ${ }^{7}$.

The occurrence of more than 254,000 envenomations in two consecutive summers, throughout Rio Grande do Sul State are 
recorded in this report. Data was obtained from the $9^{\text {th }}$ Battalion of the Fire Brigade of the Rio Grande do Sul State. Of these, 193,111 envenomations were recorded between December 15, 2017 and March 3, 2018 and 57,634 were recorded between December 15, 2018 and January 25, 2019. The state was not described as being subject to outbreaks, although it presents sporadic injuries and is in the South Region, an area where cnidarian envenomations are common and seasonal. The main beaches are located on the north coast of the state, between Tramandaí and Torres. In the Tramandaí estuary $\left(29^{\circ} 97\right.$ 'S, $\left.50^{\circ} 11^{\prime} \mathrm{W}\right)$, samplings with waiting nets recorded the presence of $O$. sambaquiensis specimens as the only toxic species among the jellyfish collected on December 7, 2019 (Figure 1). On the southern coast of the state, the jellyfish collection, performed by means of 10-min bottom trawls, aboard the Larus Oceanographic Speedway of the Federal University of Rio Grande, showed a high number of specimens of O. sambaquiensis. A total of 153 jellyfish of this species $(\sim 63 \%$ of the jellyfish collected) were collected in São José do Norte $\left(32^{\circ} 14\right.$ 'S, $\left.52^{\circ} 02^{\prime} \mathrm{W}\right)$, plus 9 jellyfish $(100 \%$ of the jellyfish collected) at the entrance of the Patos Lagoon estuary $\left(32^{\circ} 15\right.$ 'S, $52^{\circ} 02^{\prime} \mathrm{W}$ ) on December, 212018 . The absence of other endemic species causing accidents (e.g. C. lactea and cubomedusae) along these samplings shows that aggregations of $O$. sambaquiensis were responsible for the outbreak observed this summer.

The seasonal pattern of occurrence of the species on the coast of Rio Grande do Sul is similar to that occurring on the northern coast of Argentina, where the population peaks of the species are observed during the summer, resulting in a large number of envenomations in swimmers ${ }^{10}$. In other regions of Brazil, the species occurs throughout the year, but in greater abundance during distinct periods of high season, such as during winter on the south coast of São Paulo, autumn-winter in Rio de Janeiro and Paraná and spring in Florianópolis ${ }^{11}$.

The envenomations observed caused moderate-to-severe pain in all cases and were manifested by irregular plaques and short linear marks, compatible with the injuries caused by $O$. sambaquiensis ${ }^{9}$. There were no severe envenomations, despite the large number of occurrences. Treatment with ice marine water compresses and vinegar baths was used massively and was successful in reducing the intensity of pain in patients. The description of this outbreak was carried out in the observations of the authors and data of the Fire Department of Rio Grande do Sul State. Only one case was documented in the place, which disallows this communication of an authorization of Ethics Committee in Human Experimentation.

The images demonstrate typical cases that have been observed in patients affected by the outbreak, with initial short, linear plaques of the urticariform aspect, that evolved to superficial necroses, giving a hyperchromic aspect to the lesions (Figure 1). We conclude that the outbreaks are now seasonal in the South region and that the species involved do not cause major envenomations, but vital efforts are needed to prevent injuries and to provide information to the local population.

\section{Conflict of interest}

The authors declare that there is no conflict of interest.

\section{REFERENCES}

1. Rossetto AL, Dellatorre G, Silveira FL, Haddad Jr V. Seabather's eruption: a clinical and epidemiological study of 38 cases in Santa Catarina State, Brazil. Rev Inst Med Trop São Paulo. 2009;51(3): $169-75$.

2. Resgalla Jr C, Rosseto AL, Haddad Jr, V. Report of an outbreak of stings caused by Olindias sambaquiensis Muller, 1861 (Cnidaria: hydrozoa) in Southern Brazil. Braz J Oceanogr. 2011;59(4):391-6.

3. Haddad Jr V, Virga R, Bechara A, Silveira FL, Morandini AC. An outbreak of Portuguese man-of-war (Physalia physalis - Linnaeus, 1758) envenoming in Southeastern Brazil. Rev Soc Bras Med Trop. 2013;46(5):641-4.

4. Haddad Jr V, Marangoni S, Toyama D, Souza AJ, Oliveira SC, Toyama M. Identification of two novel cytolysins from the hydrozoan Olindias sambaquiensis (Cnidaria). J Venom Anim Toxins Incl Trop Dis. 2014;20:1-6.

5. Marques AC, Haddad Jr V, Rodrigo L, Silva EM, Morandini AC. Jellyfish (Chrysaora lactea, Cnidaria, Semaeostomeae) aggregations in Southern Brazil and consequences of stings in humans. Lat Am J Aquat Res. 2014;42(5):1194-99.

6. Pereira JCC, Spilzman D, Haddad Jr V. Anaphylactic reaction/ angioedema associated with jellyfish sting. Rev Soc Bras Med Trop. 2018;51(1):115-7.

7. Haddad Jr V, Morandini AC, Rodrigues LE. Jellyfish blooms causing mass envenomations in aquatic marathonists: report of cases in S and SE Brazil (SW Atlantic Ocean). Wilderness Environ Med. 2018;29(1):142-5.

8. Haddad Jr V, Silveira FL, Cardoso JLC, Morandini AC. A report of 49 cases of cnidarian envenoming from southeastern Brazilian coastal waters. Toxicon. 2002;40(10):1445-50.

9. Haddad Jr V, Migotto AE, Silveira FL. Skin lesions in envenoming by cnidarians (Portuguese man-of-war and jellyfish): etiology and severity of the accidents on the Brazilian Coast. Rev Inst Med Trop São Paulo. 2010;52(1):43-6.

10. Chiaverano L, Mianzan H, Ramírez F. Gonad development and somatic growth patterns of Olindias sambaquiensis (Limnomedusae, Olindiidae). Hydrobiologia. 2004; (1-3):373-81.

11. Nogueira M, Nagata RM, Haddad MA. Seasonal variation of macromedusae (Cnidaria) at North Bay, Florianópolis, southern Brazil. Zoologia. 2011;27(3):377-86. 